\title{
Fluidized Bed Superheated Steam Dryer for Bagasse: Effects of Particle Size Distribution
}

\author{
Luz Stella Polanco ${ }^{*}$, Vadim Kochergin ${ }^{2}$, Jose F. Alvarez ${ }^{3}$ \\ ${ }^{1}$ Audubon Sugar Institute, Louisiana State University AgCenter, Saint Gabriel, USA \\ ${ }^{2}$ Amalgamated Research LLC, Boise, USA \\ ${ }^{3}$ Sugar Cane Growers Cooperative of Florida, Belle Glade, USA \\ Email: 'spolanco@agcenter.lsu.edu, vkochergin@arifractal.com,jfalvarez@scgc.org
}

Received July 6, 2013; revised August 5, 2013; accepted September 3, 2013

Copyright (C) 2013 Luz Stella Polanco et al. This is an open access article distributed under the Creative Commons Attribution License, which permits unrestricted use, distribution, and reproduction in any medium, provided the original work is properly cited.

\begin{abstract}
Fluidized bed superheated steam drying is one of the technologies successfully applied to drying pulp in the sugar beet industry. It has the technological advantages of energy efficiency and safety (inert environment) required for use in drying bagasse. A comparison of the particle size distribution of bagasse and beet pulp was evaluated in terms of fluidization. The size distribution of bagasse particles is from 2 to 10 times broader than the equivalent distribution of beet pulp particles. The mean particle size of the bagasse is $1 / 3$ of the mean size of the beet pulp. Fluidization tests proved that bagasse fluidization is possible. It was found that beet pulp and bagasse particles clearly differ on shape and size distribution which in turn will affect the design of the ancillary equipment and the fluidization systems if sugarcane bagasse is to be dried using superheated steam technology.
\end{abstract}

Keywords: Biomass; Bagasse Drying; Particle Size; Fluidized Bed

\section{Introduction}

Feasibility studies of proposed biomass processing plants for production of biofuels or biochemicals require serious consideration of energy balances, especially steam generation. As in the cane sugar industry, biorefineries processing grassy biomass materials, such as energy cane and sweet sorghum, will extract juice as the first stage. The residue left from this stage-bagasse, would be expected to contain about $50 \%$ moisture and can be used as a fuel to satisfy power requirements of the biorefinery. Bagasse in surplus of energy requirements can be available for further conversion to other products. Reduction of bagasse moisture to a range between $10 \%-40 \%$ increases fiber preservation during storage, gives efficient and stable operation to those boilers using it as a fuel, lowers emission, and gives higher energy efficiency and higher product quality for thermochemical conversion technologies [1]. This moisture content cannot be attained with conventional mechanical/milling methods. Alternative technologies for bagasse drying deserve consideration prior to biorefinery construction.

"Corresponding author.
Physical properties of bagasse that are related to its origin make it a difficult material to process. Both the particle size distribution and the behavior of assemblies of bagasse particles are important considerations for the selection and design of equipment for feeding, collection, burning, depithing, pneumatic transportation, separation of dust, pelletizing and drying.

Bagasse drying has not been widely used because of additional costs and fire hazards; however, it is justified by plants with high energy demand. Flue gas dryers such as the rotary and the most recently pneumatic and cyclonic dryers have been the favored technologies for drying bagasse to a moisture content of $30 \%-40 \%$ [2-4]. The fluid bed pressurized superheated steam dryer (Figure 1), which is successfully used to dry beet pulp, offers a high evaporation capacity, reduction of emissions from the dryer, reduction of fire and explosion hazards and the possibility of heat recovery to increase the overall energy efficiency of factory operations. These features and the possibility of final moisture between $10 \%-20 \%$ show the advantage of a superheated steam dryer over conventional bagasse dryers $[3,4]$.

In a fluid bed dryer, the bagasse bed is expanded by the drying medium (pressurized superheated steam) which is 

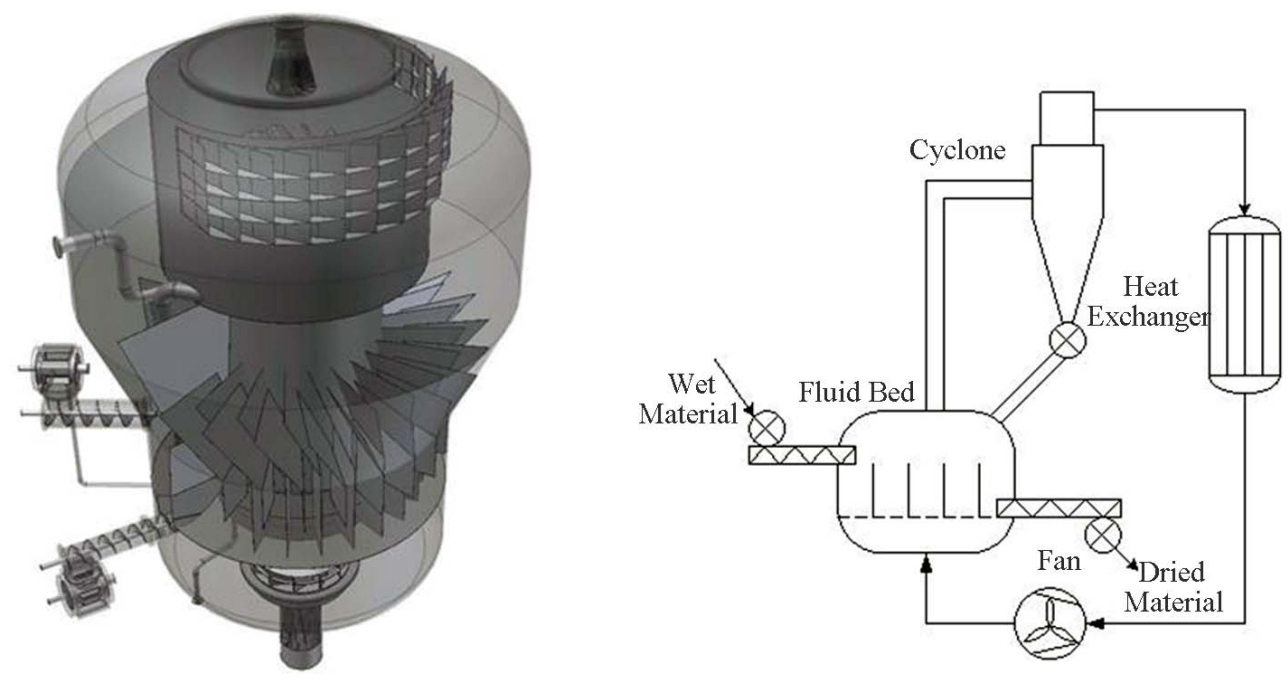

Figure 1. Pressurized superheated steam dryer and basic operation scheme showing the main components of the dryer such as: inlet and outlet, fluidization cells, dust separation system, heat exchanger and fan $[5,6]$.

injected upward. Steam and bagasse are transported together (like a single phase fluid) passing through several fluidization cells to a collection point where the dried bagasse particles are separated from the combined streams of superheated steam and evaporated moisture. The released vapor still superheated, entrains fine particles (dust) which are separated by internal cyclones [7]. Temperature, pressure and velocity of the gas as well as particle size, density change (moisture content change), height and bed void are parameters that affect the stability of the fluid bed. Geometrical configuration and dimensions of the fluidization chambers, recirculation of coarse particles, dust separation system and design of grid plates and gas spargers are design details for the success of a dryer on a large scale.

Particle size distribution affects handling, influences the retention time and causes elutriation in the fluid bed and at the cyclones [8]. There are several publications on empirical correlations, based on particle size, for handling properties and fluidization parameters for wet and dry bagasse - in equilibrium with the relative air humidity $\sim 10 \%$ moisture content [9-14]. These empirical fluidization correlations are intended to establish a minimum entrainment speed for pneumatic transport. The correlations give only proximate information for the design of a fluid bed; however the performance of the fluid bed cannot be predicted from these correlations. The quantification of bagasse characteristics and comparison with the materials that are successfully dried by superheated steam dryers (beet pulp) is important information that is currently missing. Comparative analysis of particle size distribution between beet pulp and bagasse can yield an insight for designinga pressurized superheated steam dryer for bagasse.
Particle size distribution is a mathematical function which describes the relative frequency of a given particle size with respect to the whole sample [8]. Normal and log-normal or Weibull distribution functions are used to describe the relative frequency of a given particle size [15]. Typically, the statistical parameters which describes particle size distribution are mean, mode, standard deviation, skewness (the symmetry or preferential spread to one side of the average - tail), kurtosis (concentration relative to the average), and several cumulative percentile values (the size at which a determined percentage of particles are larger or coarser) $\mathrm{D}_{10}, \mathrm{D}_{50}, \mathrm{D}_{90}$. Other relations are used also to describe the distribution such as $\mathrm{D}_{90} / \mathrm{D}_{10}$, $\mathrm{D}_{90}-\mathrm{D}_{10}, \mathrm{D}_{75} / \mathrm{D}_{25}$ and $\mathrm{D}_{75}-\mathrm{D}_{25}$; the span or width of the distribution can be calculated from $\left(\mathrm{D}_{90}-\mathrm{D}_{10}\right) / \mathrm{D}_{50}[16]$.

For a sample with a wide particle size distribution, sieve analysis is carried out for the coarse fraction while for the finer fraction another type of size measurement is required [8]. Sieve analysis has been the traditional sizing technique applied to bagasse, but bagasse fibers on sieve analysis can pass through the screen with longer sieving times and these fibers can also interlock with high volume of samples. Therefore, a standardized procedure is necessary that fixes both the sample volume and the sieving time [12]. Particle size distribution of bagasse is expected to vary from each factory due to different knifing, shredding and milling as well as sampling techniques. Natural segregation of particles according to size and particle density is common during storage [17]. Particle size distribution of bagasse is in some degree reproducible when the feedstock is well prepared, such as for a preparation index $\sim 90$ (following the International Commission for Uniform Methods of Sugar Analysis-ICUMSA procedure). The goal of this document is to 
compare the particle size distribution of sugarcane bagasse with beet pulp relative to its implications for using a fluidized bed superheated steam drying system.

\section{Materials and Methods}

\subsection{Materials}

The Amalgamated Sugar Company LLC (season 2009/10) supplied two samples of dried beet pulp and several bagasse samples from different locations and pretreatments were taken during the 2010 sugarcane season in Louisiana:

- Enterprise factory bagasse piled in 2009 with one year of outdoor storage (EPM09-P) - Cane Preparation: 2 sets of revolving knives, first with 30 blades at $600 \mathrm{rpm}$ and the second with 70 blades at $750 \mathrm{rpm}$, and one Tongaat shredder at $1200 \mathrm{rpm}$. Milling Tandem of 24 rolls [18].

- Enterprise factory diffuser bagasse piled in 2009 with one year outdoor storage (EPD09-P) — Cane Preparation: one set of knives and one heavy duty shredder. Two set of dewatering mills with 4 rolls each [18].

- Saint Mary factory bagasse piled in 2009 with one year outdoor storage (SMM09-P) - Cane Preparation: 2 sets of knives conventional rotation, first with 63 blades at $750 \mathrm{rpm}$ and the second with 60 blades at $750 \mathrm{rpm}[18]$.

- LaFourche factory bagasse, piled in 2007 \& 2009, with 3 years and 1 year of outdoor storage (LFM07-P \& LFM09-P) and fresh bagasse taken from conveyor in 2010 (LFM10-C) — Cane Preparation: One single revolving knife set with 52 knives and a Fiberizer at $1200 \mathrm{rpm}$ [18].

\subsection{Methods}

Bagasse samples $(\sim 5 \mathrm{~kg})$ were carefully homogenized in sample bags and subsamples of approximately $100 \mathrm{~g}$ were taken and placed in disposable aluminum foil cups.
Wet samples were dried in a convection oven at $75^{\circ} \mathrm{C}$ for 12 hours and then were left inside a hood for 24 hours, to reach the moisture in equilibrium $(\sim 10 \%)$ with the relative humidity of the air in the laboratory. Bagasse moisture was determined in a Sartorius Mark 3 Moisture Analyzer before sieving. An absolute total weight loss less than $2 \%$ the weight initial sample is considered acceptable [19].

Sieving tests were performed on a Retsch Sieving Machine Type AS200, dividing each test in two consecutive sections of 30 minutes (maximum number of sieves is 6). The first section had 5 sequential sieves with openings of 9.5, 4.0, 2.8, 2.0 and $1.4 \mathrm{~mm}$. The samples that passed through the smallest screen were further separated in a round of sieving with 6 sequential sieves with openings of $1.0,0.85,0.60,0.425,0.250$ and $0.125 \mathrm{~mm}$. Sieving parameters were amplitude $2.5 \mathrm{~mm} / \mathrm{g}$, acceleration $10 \mathrm{~g}\left(98.1 \mathrm{~m} / \mathrm{s}^{2}\right)$ and intervals $10 \mathrm{sec}$.

The fraction of the bagasse particles with sizes below $125 \mu \mathrm{m}(0.125 \mathrm{~mm})$ were dispersed in water and analyzed in the CILAS 1180 Particle Size Analyzer. The instrument measurement range goes from 0.04 to 2500 $\mu \mathrm{m}$; the measurement technique is based on the laser diffraction of the light source and in the wet mode, the results can be given in number or in volume.

\section{Results and Discussion}

A qualitative comparison (Figures 2(a) and (b)) shows clearly that the shape of the beet pulp particle is like a flake and the small particles are almost spherical. The shape of bagasse particles is more complex, some particles are just single strings with variable $\mathrm{L} / \mathrm{D}$, other particles are conglomerates of strings with rectangular shapes (rind) and some small particles that are spherical (pith). These different shapes are an important factor for the design of a feeding and collection system of a dryer. Bagasse fibers tend to entangle and choke, being a challenge for the design of the feeding valves (rotary valves)
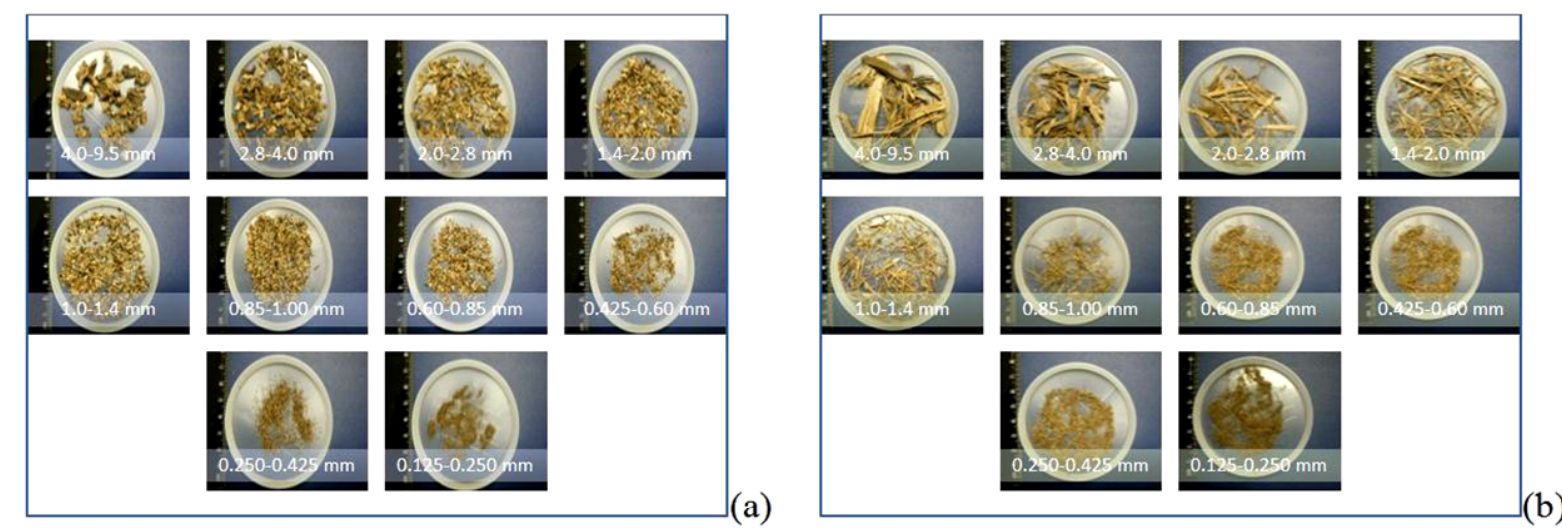

Figure 2. Pictures of particles retained between sieves during sieve analysis. (a) Beet pulp and (b) sugarcane bagasse. 
to keep pressure and a uniform feed to the bed. It is also important that rind and pith particles have different density and will behave differently during fluidization.

The particle size distribution in sugarcane bagasse depends on cane preparation and number of mills used for the juice extraction process. [2] states that the average particle size of bagasse ranges between $1-5 \mathrm{~mm}$ but can be as high as $25 \mathrm{~mm}$ when the cane preparation is poor. Some differences were found for the bagasse samples from different locations, pretreatments and sampling points in the relative weight of material retained by the sieves. The logarithmic graphs (Figures 3(a) and (b)) showed that the distributions are almost flat (low kurtosis) without a defined bell shape (no normal distribution shape).

The logarithmic graph (Figure 4) for the particle size distribution of beet pulp is skewed (tail to the left) and shows higher relative frequencies for the sieves with openings larger than $2.0 \mathrm{~mm}$. The shape of the distribution is approximately normal.

Data in Table 1 shows that the bagasse samples have a very wide distribution $\left(\mathrm{D}_{90} / \mathrm{D}_{10}\right.$ ratio from 10 to 50 and $\left(\mathrm{D}_{90}-\mathrm{D}_{10}\right) / \mathrm{D}_{50}$ span from 3 to 8 ) compared to the beet pulp $\left(\mathrm{D}_{90} / \mathrm{D}_{10}\right.$ ratio $\sim 5$ and $\left.\mathrm{D}_{90}-\mathrm{D}_{10}\right) / \mathrm{D}_{50}$ span $\left.\sim 2\right)$. The range of
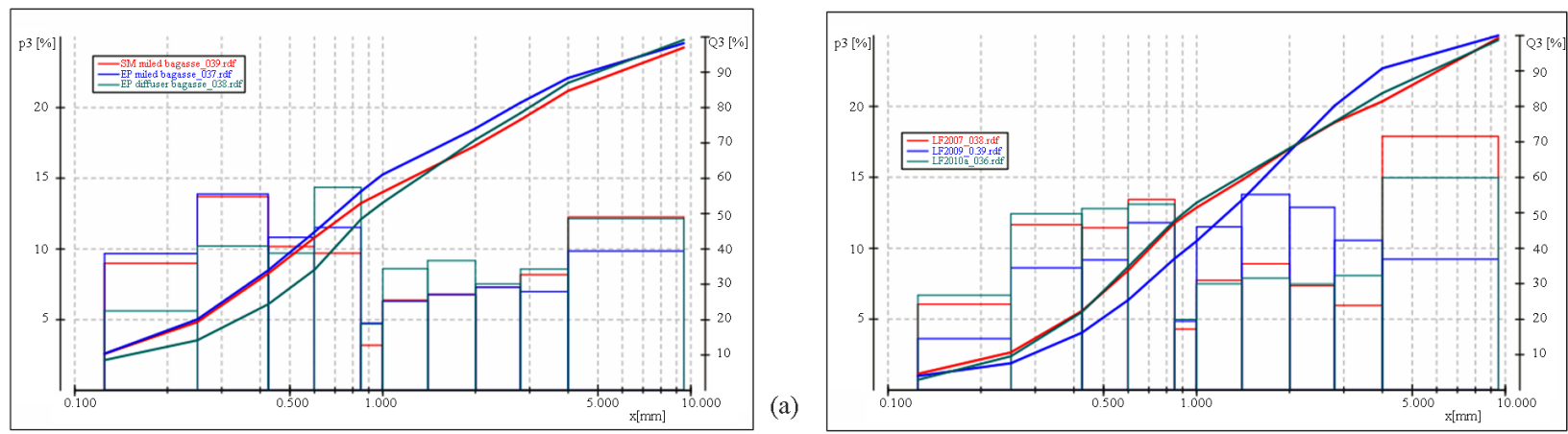

(b)

Figure 3. Relative and cumulative-logarithmic graphs for particle size distribution of bagasse by sieving. Primary y axes: p3 [\%] relative frequency — bars, secondary $y$ axes: $Q 3$ [\%] cumulative frequency — lines and $x$ axes: $x$ [mm] particle size in $\mathbf{m m}$. (a) SMM09-Pred, EPM09-P blue and EPD09-P green. (b) LFM07-P red, LFM09-P blue and LFM10-C green.

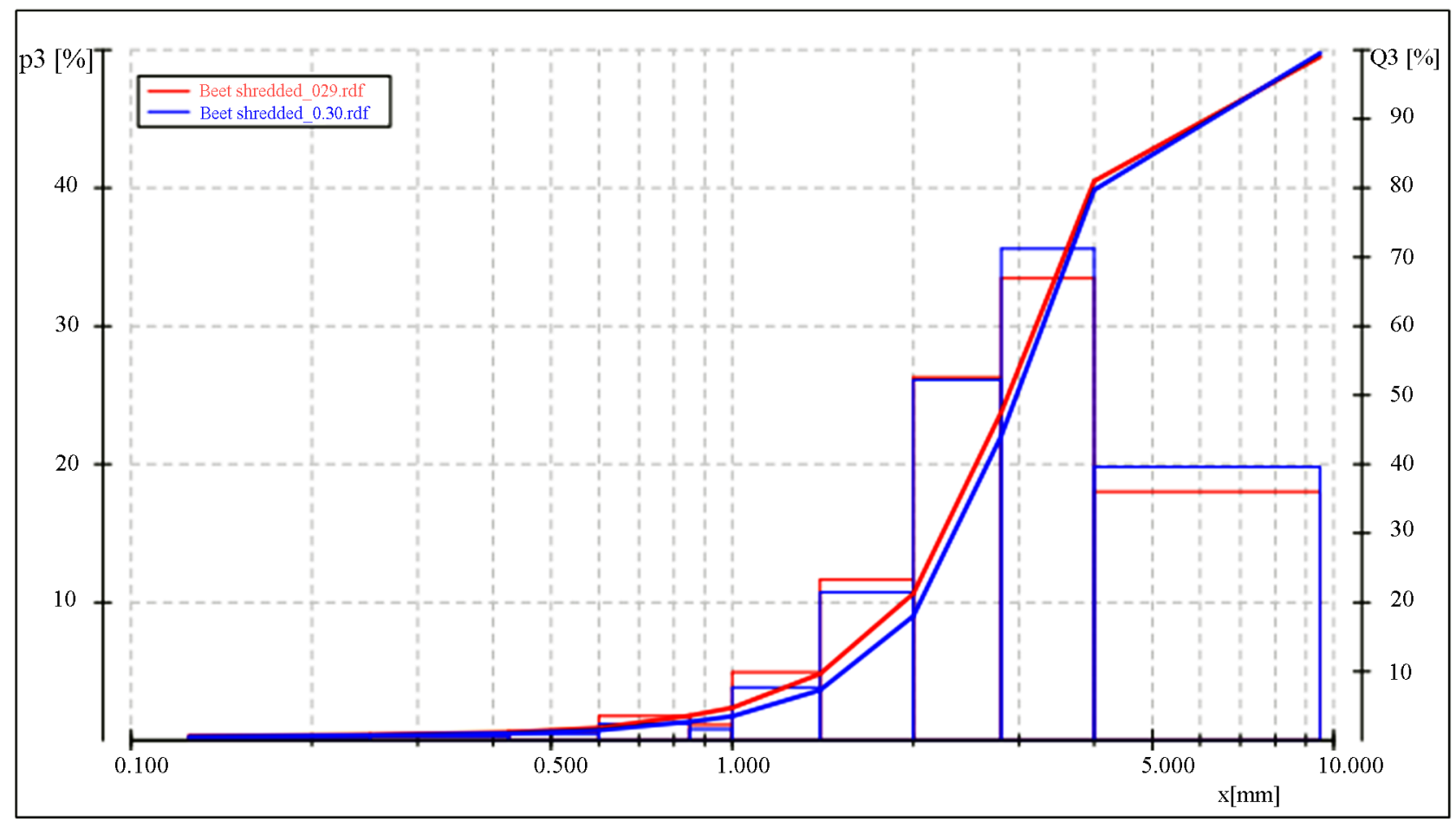

Figure 4. Relative and cumulative-logarithmic graphs for particle size distribution of beet pulp. Primary y axes: p3 [\%] relative frequency - bars, secondary y axes: $Q 3$ [\%] cumulative frequency - lines and $x$ axes: $x$ [mm] particle size in mm. BP09-10-S1 \& S2 analysis by duplicate (red \& blue). 
values for the statistical parameters derived from the particle size distribution of bagasse can be due to differing sugarcane processing for each location. The median $\mathrm{D}_{50}$ for these bagasse samples ranged from 0.7 to $1.3 \mathrm{~mm}$ compared to beet pulp for which $\mathrm{D}_{50}$ was around $3.0 \mathrm{~mm}$. These differences indicate that lower velocities can be expected for bagasse fluidization compared to beet pulp. Mass percentage of bagasse with size below $0.125 \mathrm{~mm}$ ranged from $4 \%$ to $10 \%$ while for beet pulp it was $0.6 \%$. Amount and particle size distribution of this fraction is an important consideration for the design of the dust separation system of a superheated steam dryer. Retained particles will be recycled to the fluid bed as it is desirable a very small amount of entrained particles leaving the dryer with the vapors.

The particle fractions below $0.125 \mathrm{~mm}$ retained by the sieve were analyzed using the laser diffraction instrument. Figure 5 shows the particle size distribution results for (a) beet pulp and (b) bagasse. In general, the distributions show a sharp peak with a tail to the left for both the beet pulp and the bagasse particles. It may be expected that some of the particles from the left tail of the distribution $(<10 \mu \mathrm{m})$ will be entrained in any vapor leaving the dryer.

Table 2 summarizes the particle size distribution determined by laser diffraction method. Although the samples presented to the instrument supposedly were below $125 \mu \mathrm{m}$ (from sieve analysis) the irregularity on the shape of both beet pulp and bagasse particles resulted in a fraction of larger particles present in the samples $\left(D_{90}\right.$ percentiles were above $200 \mu \mathrm{m})$. Ten percent $\left(D_{10}\right)$ of the particles that are expected to be handled by dust separation systems are below $13 \mu \mathrm{m}$ for bagasse compared to $16 \mu \mathrm{m}$ for beet pulp. Coefficient of variation $(\mathrm{CV})$ and span $\left(\mathrm{D}_{90}-\mathrm{D}_{10}\right) / \mathrm{D}_{50}$ are similar for all the samples.

Particle size distribution has a major impact on fluidi

Table 1. Particle size distribution of sugarcane bagasse and beet pulp. Sieving tests with samples at equilibrium moisture $(\sim \mathbf{1 0} \%)$.

\begin{tabular}{|c|c|c|c|c|c|c|}
\hline \multirow{3}{*}{ Sample Description } & \multicolumn{5}{|c|}{ Restch Sieving Machine (0.125 - $9.5 \mathrm{~mm})$} & \multirow{2}{*}{$\begin{array}{c}\text { Particles } \\
\leq 0.125 \mathrm{~mm} \\
\end{array}$} \\
\hline & $D_{10}$ & $\mathbf{D}_{\mathbf{5 0}}$ & $\mathbf{D}_{90}$ & $\mathbf{D}_{90} / \mathbf{D}_{10}$ & $\left(\mathbf{D}_{90}-\mathbf{D}_{10}\right) / \mathbf{D}_{90}$ & \\
\hline & $\mathbf{m m}$ & $\mathbf{m m}$ & $\mathbf{m m}$ & Ratio & Span & $\operatorname{mass} \%$ \\
\hline Bagasse EPD09-P & 0.16 & 0.90 & 5.36 & 34.1 & 5.8 & 8.6 \\
\hline Bagasse EPM09-P & 0.12 & 0.71 & 4.90 & 40.8 & 6.7 & 10.4 \\
\hline Bagasse SMM09-P & 0.12 & 0.78 & 6.36 & 52.6 & 8.1 & 10.4 \\
\hline Bagasse LFM07-P & 0.24 & 0.95 & 6.63 & 28.0 & 6.7 & 4.6 \\
\hline Bagasse LFM09-P & 0.30 & 1.28 & 3.92 & 13.1 & 2.8 & 4.0 \\
\hline Bagasse LFM10-C & 0.21 & 0.80 & 4.45 & 20.8 & 5.3 & 4.0 \\
\hline Beet pulp BP09-10-S1 & 1.42 & 2.89 & 6.75 & 4.8 & 1.8 & 0.6 \\
\hline Beet pulp BP09-10-S2 & 1.55 & 3.00 & 6.86 & 4.4 & 1.8 & 0.5 \\
\hline
\end{tabular}

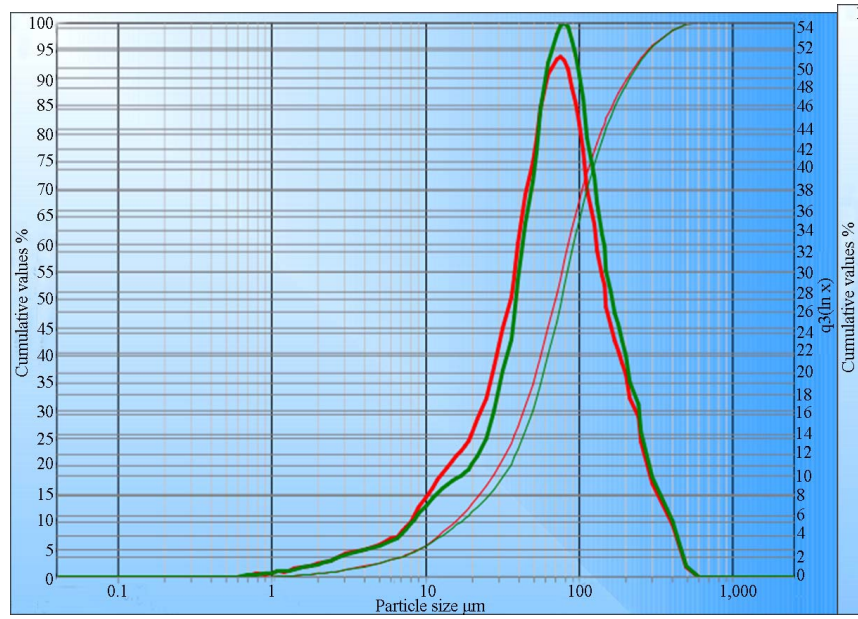

(a)

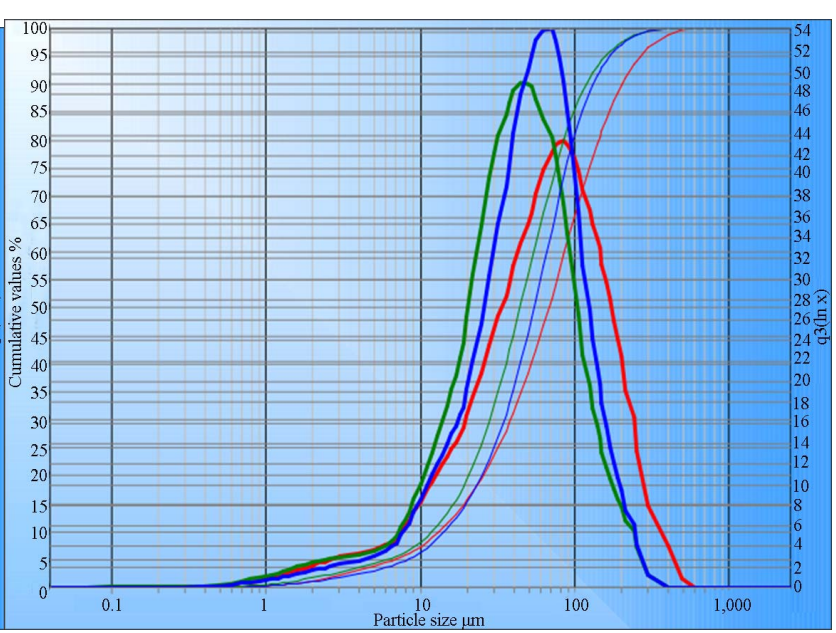

(b)

Figure 5. Particle size distributions by laser diffraction of the fraction below $0.125 \mathrm{~mm}$. Primary y axes: Q3 [\%] cumulative frequency, secondary $y$ axes: $q 3$ [In $x$ ] relative frequency and $x$ axes: particle size in $\mu \mathrm{m}$. (a) Beet Pulp BP09-10 analysis by duplicate (red \& blue) and (b) Bagasse EPM09-P red, EPD09-P green and SMM09-P blue. 
Table 2. Particle size analysis by laser diffraction for beet pulp and bagasse particles below $0.125 \mathrm{~mm}$.

\begin{tabular}{|c|c|c|c|c|c|}
\hline \multirow{3}{*}{ SAMPLE NAME } & \multicolumn{5}{|c|}{ CILAS Particle Size Analyzer $(<0.125 \mathrm{~mm})$} \\
\hline & \multirow{2}{*}{$\begin{array}{l}D_{10} \\
\mu \mathrm{m}\end{array}$} & \multirow{2}{*}{$\begin{array}{l}D_{50} \\
\mu \mathrm{m}\end{array}$} & \multirow{2}{*}{$\begin{array}{l}D_{90} \\
\mu \mathrm{m}\end{array}$} & \multirow{2}{*}{ CV } & \multirow{2}{*}{$\frac{\left(\mathbf{D}_{90}-\mathbf{D}_{\mathbf{1 0}}\right) / \mathbf{D}_{\mathbf{9 0}}}{\text { span }}$} \\
\hline & & & & & \\
\hline EPM09-P & 13 & 68 & 201 & 0.93 & 2.8 \\
\hline EPD09-P & 12 & 44 & 118 & 0.87 & 2.4 \\
\hline SMM09-P & 14 & 55 & 131 & 0.79 & 2.1 \\
\hline BP09-10-S1 & 16 & 69 & 204 & 0.92 & 2.7 \\
\hline BP09-10-S2 & 17 & 76 & 211 & 0.88 & 2.6 \\
\hline
\end{tabular}

Note: reported as a volume $\%$ of particulate material.

zation, plugging of the fluidization cells, feeding, product collection and dust separation in the fluidized superheated steam dryer for bagasse. Shape of the bottom of the cell and distribution of the air passages are the key features that assure stability to the fluidized bed. Bagasse particles are expected to behave differently compared to beet pulp since the mean particle size is $\sim 1 \mathrm{~mm}$ for bagasse compared to $\sim 3 \mathrm{~mm}$ for beet pulp, and the distribution span is $\sim 6$ for the bagasse particles compared to an span $\sim 2$ for the beet pulp particles. A concern is the higher percentage on weight of particles less than 125 $\mu \mathrm{m}$ for bagasse $\sim 7 \%$ compared to beet pulp $\sim 0.5 \%$.

From tests performed for fluidized bed combustion (FBC), it was concluded that bagasse cannot fluidized under normal conditions, rather it requires mixing with other inert fluidizing materials [20]. However, EnerDry (Denmark) in collaboration with Sugar Cane Growers Cooperative (SCGC) of Florida built a fluidization unit (a section of a full size dryer) and performed preliminary fluidization tests for both beet pulp and bagasse. To achieve good fluidization, improved gas distribution was required. It was achieved through modification of the geometry and open area of the perforated bottom. Finally, air velocity of $1.8 \mathrm{~m} / \mathrm{sec}$ was required to fluidize bagasse at $50 \%$ moisture compared to an air velocity of $2 \mathrm{~m} / \mathrm{sec}$ to fluidize beet pulp at the same moisture content. The required air velocity to fluidize bagasse ranged from 2.2 $\mathrm{m} / \mathrm{s}$ for approximately $60 \%$ moisture content to $1 \mathrm{~m} / \mathrm{sec}$ for approximately $10 \%$ moisture content [21]. Considerable entrainment of large particles with a flat shape was noticed, as then probably behaved as airfoils. [10] described the shape of bagasse fibers as a rectangular prism with flat parallel faces; and [9] stated that the aerodynamic behavior of the bagasse particles depends on the position of the particle respect to the air stream, thus, when the area in front of the airflow is the maximum the 'terminal velocity' is minimum. The roughness of the surface and the ends of the bagasse fibers will produce a flutter movement which will increase the drag of the particle, therefore smoothness and roundness of the ends will affect the orientation and reduce the drag [9].

\section{Conclusion}

Bagasse particles have more shape variation than beet particles. Bagasse particles can have a string like shape (fiber) or a spherical shape (pith) and they can be glued together in a flat shape (rind), while beet particles have mainly a flat rounded shape. The size distribution of bagasse particles is wider than that of the beet pulp particles, with a coarse-to-fine $\left(\mathrm{D}_{90} / \mathrm{D}_{10}\right)$ ratio that can be 2 to 10 times higher than that for the beet pulp particles whose shape distribution is closer to a bell (Gaussian or Normal distribution). The mean size of the beet particles $(\sim 3 \mathrm{~mm})$ is three times higher than the mean size of bagasse particles $(\sim 1 \mathrm{~mm})$. A stable fluid bed of bagasse was achieved in tests performed in Denmark by Enerdry, by modifying geometry and increasing the differential pressure of the bottom air distributor. Air velocities of $1.8 \mathrm{~m} / \mathrm{s}$ were required to fluidize bagasse at $50 \%$ moisture content compared to air velocity of $2 \mathrm{~m} / \mathrm{s}$ required for beet pulp with the same moisture content. The percentage of the small particles fraction $(<0.125 \mathrm{~mm})$ was as high as $10 \%$ for bagasse while for beet pulp the percentage of this fraction was just $\sim 0.5 \%$. According to laser diffraction, the size distribution of this fraction of particles is similar for both bagasse and beet were 0.13 $\mathrm{mm}$, which was the mean particle size for bagasse and $0.16 \mathrm{~mm}$, which was the particle size for beet pulp, respectively. Besides the entrainment of the small particles, larger particles with a flat shape were entrained during the fluidization tests, which was a factor that has to be considered for the design of the dust system of the dryer.

\section{Acknowledgements}

Special thanks to the Sugar Cane Growers Cooperative of Florida for sharing the reports from the fluidization tests performed by EnerDry Aps in Denmark. Also, special thanks to Iryna Tishechkina for the results of particle size analysis by Laser Diffraction of the small particle fraction. This work was funded by a grant from the American Sugar Cane League and the USDA Agriculture and Food Research Initiative Competitive Grant Award No. 2011-69005-30515.

\section{REFERENCES}

[1] S. Pang and A. S. Mujumdar, "Drying of Woody Biomass for Bioenergy: Drying Technologies and Optimization for an Integrated Bioenergy Plant," Drying Technology, Vol. 28, No. 5, 2010, pp. 690-701. http://dx.doi.org/10.1080/07373931003799236

[2] P. Rein, "Cane Sugar Engineering," Bartens, Berlin, 2007.

[3] A. S. Mujumdar, "Handbook of Industrial Drying," Boca 
Raton, CRC/Taylor \& Francis, 2007.

[4] A. S. Jensen, "Steam Drying of Beet Pulp. Larger Units, No Air Pollution, and Large Reduction of CO2 Emission," The XVth Symposium Organized by Association Andrew VanHook. Utilization of Sugars as Raw Materials for Chemical and Biotechnological Applications and Eco-Compatible Processing, Maison des Agriculteurs, Reims, 2008.

[5] A. S. Jensen, "The Innovative Separation of Water from Beet Pulp - Steam Drying. Development by Rebuilding Old Dryers," 22nd General Assembly of the International Commission for Sugar Technology, Berlin, 18-21 May 2003, pp. 347-355.

[6] A. S. Jensen, "Steam Drying of Beet Pulp. Latest Development," 33rd Biennial Meeting of the American Society of Sugar Beet Technologists, Palm Springs, 2-5 March 2005, pp. 118-125.

[7] A. S. Jensen, "Drying of Beet Pulp in Superheated Steam," The 26th Biennial Meeting of the American Society of Sugar Beet Technologists, 1991.

[8] R. B. Keey, "Drying of Loose and Particulate Materials," Hemisphere, New York, 1992.

[9] C. N. Anderson, "Aerodynamics of Bagasse Particles," The Australian Society of Sugar Cane Technologists Limited (ASSCT), 1988.

[10] N. Ponce, P Friedman and D. Leal, "Geometric Properties and Density of Bagasse Particles," International Sugar Journal, Vol. 85, No. 1018, 1983, pp. 291-295.

[11] S. A. Nebra and I. Macedo, "Bagasse Particles Shape and Size and Their Free-Settling Velocity," International Sugar Journal, Vol. 90, No. 1077, 1988, pp. 168-170.

[12] H. W. Bernhardt, "Shape Factors of Bagasse Particles," The Annual Congress-South African Sugar Technolo- gists’ Association, University of Natal, Durban, 1993.

[13] M. G. Rasul, V. Rudolph and M. Carsky, "Physical Properties of Bagasse," Fuel, Vol. 78, No. 8, 1999, pp. 905910. http://dx.doi.org/10.1016/S0016-2361(99)00011-3

[14] G. A. R. Alarcón, C. G. Sanchez, E. O. Gomez, et al., "Caracterización del Bagazo de la Caña de Azúcar. Parte I: Características Físicas," The 6. Encontro de Energia no Meio Rural, Campinas, 2006.

[15] N. R. J. Fieller, E. C. Flenley and W. Olbricht, "Statistics of Particle Size Data," Journal of the Royal Statistical Society. Series C (Applied Statistics), Vol. 41, No. 1, 1992, pp. 127-146.

[16] S. J. Blott and K. Pye, "GRADISTAT: A Grain Size Distribution and Statistics Package for the Analysis of Unconsolidated Sediments," Earth Surface Processes and Landforms, Vol. 26, No. 11, 2001, pp. 1237-1248. http://dx.doi.org/10.1002/esp.261

[17] R. H. Perry and D. W. Green, "Particle Size Analysis-Size Reduction and Size Enlargement," In: D. W. Green Ed., Perry's Chemical Engineers' Handbook, McGraw-Hill, New York, 1997, pp. 5-10.

[18] “2010/11 Gilmore Sugar Manual," Sugar Publications, Fargo, 2011.

[19] Retsch, "Operating Instructions for Sieving Machine Type AS 200 control Retsch GmbH,” 2005.

[20] M. G. Rasul and V. Rudolph, "Fluidized Bed Combustion of Australian Bagasse," Fuel, Vol. 79, No. 2, 2000, pp. 123-130. http://dx.doi.org/10.1016/S0016-2361(99)00144-1

[21] K. G. Larsen and A. S. Jensen, "Steam Drying of Bagasse Airmodel. Report to the Sugar Cane Growers Cooperative (SCGC) by EnerDry," PPT Presentation, Ågerup, September 2011. 